\title{
Compassionate Capitalism - The Pursuit of Equal Income Distribution
}

\author{
Rebeca Rodríguez Minor ${ }^{1}$ \\ ${ }^{1}$ School of Business, Universidad Anáhuac (Campus Cancun), Quintana Roo, Mexico \\ Correspondence: Rebeca Rodríguez Minor, School of Business, Universidad Anáhuac (Campus Cancun), Blvd. \\ Luis Donaldo Colosio Km 13.5, Mz.2, Zona 8, L1, Z.C. 77565, Cancún, Quintana Roo, Mexico. Tel: \\ 1-800-822-2628 / +52-998-881-7750, Ext. 142.
}

Received: October 28, 2017

doi:10.20849/ajsss.v2i4.262
Accepted: December 21, 2017 Online Published: December 25, 2017

URL: https://doi.org/10.20849/ajsss.v2i4.262

\begin{abstract}
During the last decades, the great weaknesses of capitalism have flourished. Inequality of income distribution has worsened painfully, the gap between rich and poor widens more and more every day, and just a few lucky entrepreneurs in the world are able to enjoy the capital benefits of the global system. Hunger, poverty, demographic explosion, ageing, and unbridled mass migration, among other factors, have become critical social dilemmas directly related to capitalist deviations, all of which cause us to foresee a chaotic world scenario in the near future. The numbers shown in this article confirm that the world's economic disparity, instead of diminishing, is increasing at an alarming rate. Unfortunately, since the world economy completely depends on capitalism, this system is still extremely powerful and influential in global decision-making, thus further aggravating economic disparity. Therefore, as it is not possible to avoid the capitalist system, we will make proposals that are feasible for implementing within the current capitalist tendencies in order to alleviate global imbalance. Compassionate Capitalism is an alternative that promotes flexibilization of the system in order to make it more sustainable. It seeks to diminish corporate control over the economy and markets by regaining the State's economic intervention so that profits are fairly redistributed for the common welfare. The information used for the study is based on the most recent international reports and global circumstances of the topics in question.
\end{abstract}

Keywords: compassionate capitalism, income distribution, inequality, over-amassing

JEL Classification Codes: F02, F16, F22.

Contribution/ Originality: This study is focused on analyzing how critical the situation has become regarding current global dilemmas such as income distribution inequality, demonstrating that these deviations are direct consequences of the capitalist system itself. The argument centers on the affirmation that there is no other way to alleviate these deviations other than by improving governmental tendencies towards compassionate capitalism. This is an uncommon, but very desirable concept based on the State's regulation of the economy, aimed at tackling corporate laissez-faire and control over global wealth. Although being a concept that contradicts the principles of capitalism, it is feasible to materialize compassionate capitalism within the system.

This article innovatively denotes the intrinsic correlation that exists among key economic concepts, geographic and international relations'theories, and global system's deviations like income distribution inequality. Besides that, the current study demonstrates how social phenomena like demographic explosion, mass migration and ageing, are direct consequences of worldwide economic inequality and capital over-amassing. Previous studies flaws rely on their limited scope to consider the correlation previously stated and its feasible connection with the concept of "compassionate capitalism", understood as a viable alternative to mitigate the global dilemmas.

\section{Introduction}

Nowadays, unequal income distribution has become a common asset. Awareness of the great gap between rich and poor people is spreading throughout the globe, since it is an unscrupulous and cynical condition where only the richest $1 \%$ of the world population own more wealth than the rest of the planet (OXFAM International, 2017). This critical disparity has worsened each year, and it does not appear it will get better anytime soon.

Some exceptional governments (mainly from developed countries) have adopted public policies that have alleviated the economic disparity in their communities by combining strategies and ideologies from two diverse political systems: capitalism and socialism. Thus, it is not unusual to find political parties and full governments, 
mainly known as "social democracies", which are in favor of a capitalist economic system but are also very committed to social welfare. It is in this sense that the concept of compassionate capitalism arises.

Is there any real chance for capitalism as a system to become compassionate in order to combat its own deviation? This article seeks to analyze, from a critical perspective, the deviations of capitalism that have led us to critical social dilemmas that are worsening alarmingly day by day; augmenting an argument in favor of the feasibility of a global system ruled by the alternative of an unusual asset called compassionate capitalism. This article intends to demonstrate that these controversies regarding the economic system will be solved by bringing together the private and public sector, civil society and governments, towards tendencies related to this alternative. To do so, critical thought is focused on a comparison of theories, ideologies, case studies, and data analysis.

\section{Methodology}

This is a descriptive, correlational, and explanatory investigation with a purely qualitative focus since it is founded on the collection of documental date that bases its argument on the validity and reliability of bibliographical resources used as key sources. The tangible reality affecting the world economic system structure is defined using the results obtained from this study, basing the argument and proposals on prior experience, understanding of the subject, and the collection of genuine, updated, diverse, and reliable information. There is no manipulation of the variables. This is an external observation of the occurrence in its natural form, and it is defined as research-based theory founded on emerging design; this means that the theory comes from the information itself-it is not forced into categories. The type of sampling is theoretical, i.e., the collection of the information and the emerging theory will indicate the composition of the sample. (Hernández et al., 2010)

To achieve the main objective of this investigation, world income distribution is comparatively analyzed through the last few years. It is carried out purely in a current timeframe, emphasizing the argument of how inequality and over-amassing are prevailing not just in worldwide wealth distribution, but are also increasing at an alarming rate that allows us to foresee an uncontrolled critical situation in the near future. This shocking approach leads us to address the problems associated with world population, such as demographic explosion, uncontrolled mass migration, scarcity, lack of quality of life, and social discontent, all of which have become regular aspects of daily life.

These findings allow us to raise awareness of how the continuance of these social hurdles, as the consequence of a distorted world capital share, are accelerating the decline of the global system.

The proposals are centered on the discussion of plausible theoretical and practical options to reducing the global imbalance. Among other ideas, the core concept to be approached in this section is Compassionate Capitalism, which is understood as an alternative to managing capitalism, avoiding its worst deviations. State economic regulation, corporate social responsibility, and civil empowerment are brought together into a common goal: to fairly distribute national wealth among all social sectors.

The information used for the study is based on the most recent international reports and global circumstances of the international economic system; it is focused on global wealth distribution, income distribution, economic growth and development and the social patterns associated with them. This investigation took place in the year of 2017 over a four-month period.

\section{Review of the Literature}

In order to understand the context in which Compassionate Capitalism would evolve in the global system, it is necessary first to address the neglected cycle into which the interaction of income distribution, social-labor relations and international markets have fallen. Let us start by gaining a better understanding of the main concepts and theories related to this subject.

\subsection{The concepts: Economic Growth and Development}

Every nation in the world seeks to create, promote, and improve social development for their societies. At least in theory, that's what governments are willing to achieve. However, what the majority of periphery societies face every day is economic weakness, lack of quality of life, low-paid and scarce job creation, among other factors, all of which translate into social discontent, violence, and crime, along with terrorism and the mass migration boom. One of the biggest reasons for this situation is that capitalism is an economic theory that causes people to confuse essential concepts related to prosperity, sustainability, and human development.

Capitalism is based on the principle that capital accumulation and wealth are the key elements for success and good quality of life. The more you earn, according to the theory, the more you prosper. Thus, economic growth is 
frequently associated or even confused with the term, economic development. However, these two concepts are dissimilar and not necessary related. The current world situation demonstrates this statement very well.

For instance, when we talk about "economic growth", we are only referring to the amount of capital a nation is capable of accumulating (GDP), while "development", refers to the possibility of having an efficient and sustained economy that allows you to enjoy a prosperous standard of life. To achieve this stage, equal income distribution, access to basic services such as good governance, education, housing, and health, along with added value in jobs and wages, are all core assets that must be addressed.

Official definitions of these concepts are well described by Alina-Petronela Haller (2012):

Economic Growth: "[...] is, in a limited sense, an increase of the national income per capita [...], and it involves the increase of the GDP, GNP and NI, therefore of the national wealth, including the production [...]".

Development: "[...] is a process that generates economic and social, quantitative and, particularly, qualitative changes, which causes the national economy to cumulatively and perpetually increase its real national product." (Haller, 2012:66)

Just as economic growth is related to the size of national economies, development is associated with living standards.

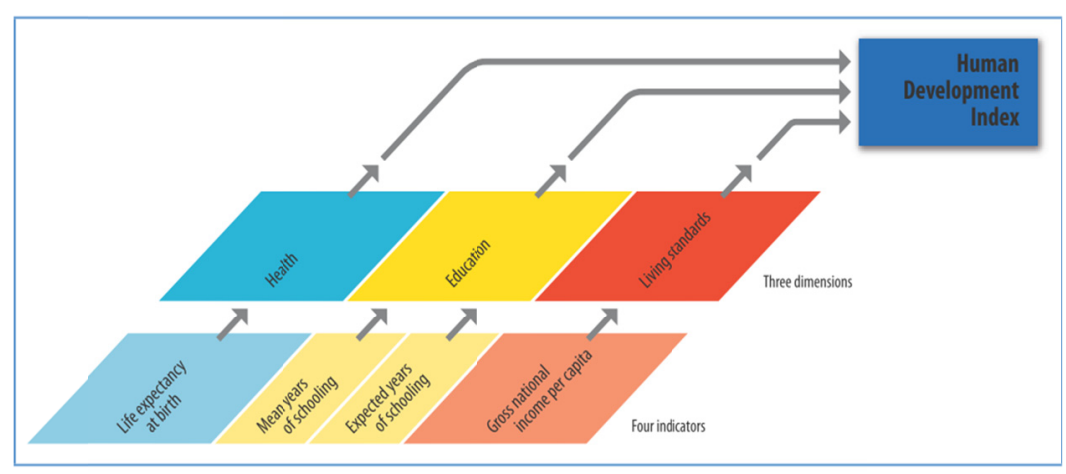

Figure 1. Components of the human development index

Source: UNDP, 2010

Therefore, when we have economic growth, it does not necessarily mean we are achieving internal development, because the capital might be distributed in an ascendant, rather than linear direction (Haller, 2012). Thus, even though a nation can report a great year in terms of economic growth, its human development stage might be the same as the previous one.

It is very common to find governments boasting of their economic growth progress; however, as that income is rarely well distributed among the population, that progress might be counter-productive if only a few individuals are obtaining the direct benefits of it.

It would be unfair to lay out only a negative perspective of the economic growth-development inter-relationship. Economic growth may imply improvement in human development as well, but mainly under circumstances where economic income is resourcefully channeled into growth of human welfare.

As an example of this concept, we can see quite a successful social program in Brazil. This South American country, one of the most unequal nations on earth in terms of income distribution, created a social program called Bolsa Familia. It was a political initiative from former president Luiz Inácio Lula Da Silva, whereby giving money (increasing income) to the poorest sectors of society has made it possible for millions of its inhabitants to increase their living standards as well as to move from extreme poverty, to poverty or middle class levels.

At the end of the $20^{\text {th }}$ century, one third of the Brazilian population was living below the poverty line, surviving on only $\$ 2$ a day, while $15 \%$ of the population was below an extreme poverty base of $\$ 1.25$ a day (Tepperman, 2015). Nonetheless, only one decade later, Brazil was able to reduce poverty by half (from $9.7 \%$ to $4.3 \%$ ), thanks to Bolsa Familia, which reached one quarter of the entire population (around 50 million low-income people). 
The program works by transferring conditional cash (around $\$ 30$ usd) to the poorest families on a monthly basis. In exchange for the money, parents are obligated to send their children to school and perform diverse sanitary controls as well (Ceratti, 2014). The great success achieved by this program has caused governments from all over the world to learn and replicate the same social strategy in their own countries.

It seems to be that, as long as the money is conditional to human welfare assets, economic growth can improve human development.

\subsection{The theories: Environmental Determinism vs Possibilism}

There are diverse theories of geography. One of them, possibilism, states that people can achieve success and a prosperous life even though they were born into conditions of misery. They argue that geography and environment are not elements that influence human prosperity, evolution and development. Individual commitment and drive cause human beings to obtain whatever they want in life. On the other hand, there is the theory of environmental determinism, which affirms that the physical environment and geographical conditions into which a human being was born have an enormous impact and control over his individual capabilities as well as having a huge impact on the composition and structure of entire societies, including a society's development status and economic growth (Fekadu, 2014).

There is still a profound debate related to these two theories; however, the predominant capitalist system in which the world interacts may fit better into the theory of environmental determinism. Underdeveloped countries are condemned, in this system, to be subordinate to the developed ones, while their inhabitants become a cheap labor force and suppliers of raw materials for the benefit and welfare of other countries. This deceptive reality happens not only among nations, it also affects labor relations within societies. If we look at the scope of this economic theory on a smaller scale, we see how capitalism promotes the huge economic disparity between rich and poor people. The poorest sectors of societies must permanently depend on the scarce jobs offered by the wealthiest; the wealthiest amass exorbitant quantities of capital originating from the exploited workers who are, in turn, the consumers.

\section{As the UNDP states:}

"People with certain characteristics, in certain locations, and with certain identities are more likely to lack access to essential services and opportunities and are more prone to be victims of discrimination and other forms of social exclusion." (UNDP, 2016:94)

From a global perspective, Wallerstein (2004) gives us a good explanation of this phenomenon in his world-system theory: all the high-profit consumer goods of worldwide markets, which are mainly ruled and produced by core (northern) countries and their multinational corporations, are distributed around the globe, including to semi-periphery and periphery (southern) nations, who are the ones who not only consume such goods, but who also provide the raw materials and cheap labor to make it possible for the core nations to produce said high profit goods.

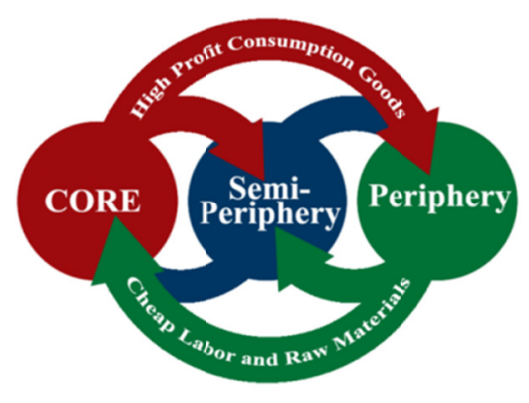

Figure 2. Wallerstein's world-systems theory model

Source: Guinote, 2013.

Core countries are those that have been at the top of the global order since the first industrial revolution. They have been able to establish a healthy internal economy and productive structure based on top industrialization and 
political leadership. Therefore, they are able to rule the international arena, as they are the pioneers of technological readiness, business innovation, market trends, and capital distribution.

Periphery nations are the ones that have been unable to achieve internal self-sufficiency, thus remaining behind in their economies, which are dependent on the core countries. Their industrial and productive sectors are weak, shattered, and inefficient, so their effectiveness is determined and structured according to the terms and interests of the superpowers.

In the third stage we find the semi-periphery countries, which share mutual conditions from both types of nations. On the one hand, they can have great assets in terms of productivity and/or economic efficiency - bringing them closer to the northern scale - while, on the other hand, they face other vulnerability factors (mainly related to the scarcity of social welfare and lack of political democracy), which causes them to remain significantly behind the north, and therefore, more related to the underdeveloped world.

The most representative semi-periphery nation would probably be China. Even with its capacity to generate an enormous, productive economy, it has not been able to achieve the same developmental standards as the superpowers. This is due to the existence of key social and political standards that are still in the rudimentary stages. Red tape, labor exploitation, authoritarian governance, institutional corruption, among others, cause them to be in a constant struggle for a leadership position in the global order. They might be good at strategic alliances and market trends, since its powerful economy allows them to be, but it is still difficult to see them as world rulers, as long as their internal structure is still so deviated. Thus, the international arena continues being controlled by the traditional core countries.

The world has resorted to a co-dependent, cyclical economic structure that only "works" in terms of domination subordination co-relations (Cuevas \& Rodríguez; 2017). As the Globalist Theory states (Kauppi \& Viotti, 2012), the core countries are unwilling to share their economic and political power with the periphery countries. They will continue controlling the system in order to continue stockpiling their economies with the capital that comes from the south.

Based on the above statements, we can conclude, then, that the theory of possibilism might be plausible in exceptional cases where only a few people and countries are able to overcome their underdeveloped status by putting forth admirable efforts in the powerful struggle against the dominant capitalist system.

\section{Results / Analysis}

\subsection{World Income Distribution in Two Words: Unequal and Over-Amassing}

There are many studies related to income distribution. All of them point to one conclusion: Economic income and global wealth in general are distributed in a manner that is alarmingly unequal. Therefore, it is necessary to understand and be aware of the worrisome situation we are facing every day.

In relation to inequality, underdeveloped countries and, specifically, underdeveloped urban cities such as Rio de Janeiro, Mexico City or Bombay, clearly show how overcrowding has overwhelmed urban life. In this type of communities, it is common to see extremely poor regions surrounding "prosperous" cities, where wealthy families, well-educated people, innovative businesses, and upscale buildings remind the poor sectors just how unfair life can be. While they do not have access to good education, a worthy salary or a decent house, other inhabitants, just a few blocks away, enjoy a privileged life full of benefits unavailable to others. In the poorest sectors, this painful disparity generates feelings of frustration and impotence for the unattainable living standards that others happily enjoy. That frustration is transformed into serious urban deviations such as violence, crime, informal jobs, and drug trafficking, among others.

As Thomas Piketty creatively demonstrated in his book "Capital in the Twenty-First Century" (2014:431), we are facing a radical global divergence of distribution of capital due to the fact that rich people can make more money than the poor only from the revenues and benefits they are able to obtain while investing huge amounts of money in stock portfolios. He compares this to the minimum quantities that the majority of the world's population manages to accumulate, obtaining a return on capital that is significantly less, percentage-wise, than what the richest obtain. As the author claims, it is also easier for rich people to undertake risky strategies that help them obtain greater advantages and benefits from the stock exchange. This dilemma, among other elements that we will discuss later, is causing world wealth to become more concentrated (over-amassing) into only a few persons - persons, not even corporations - because the great fortunes that continue growing belong to individuals, mainly resulting from family inheritance (Piketty, 2014). As the latest investigation by OXFAM International (2017) states, only 8 people (males) in the world have amassed the same quantity of wealth as 3.6 billion people combined. (OXFAM International, 2017:1) 
What we are facing is alarming, not only because of the spectacular quantity of money that only one person can hold, but also because it seems to be that the money rich people accumulate is coming from the bottom up. This means that the poor are sharing less money among themselves, since that money is going to the rich. According to Piketty's analysis, the growth rate of top global wealth between 1987 and 2013, shows how the biggest fortunes always have the greatest growth. While the top $1 \%$ highest wealth holders have grown their average rate of wealth over $6.8 \%$ per year, regular adults have only increased their wealth an average of $2.1 \%$ (Piketty, 2014: 435).

To have a better perspective of the severity of the problem stated above, see Graph 1, which shows a global wealth pyramid comparison between 2015 and 2016.

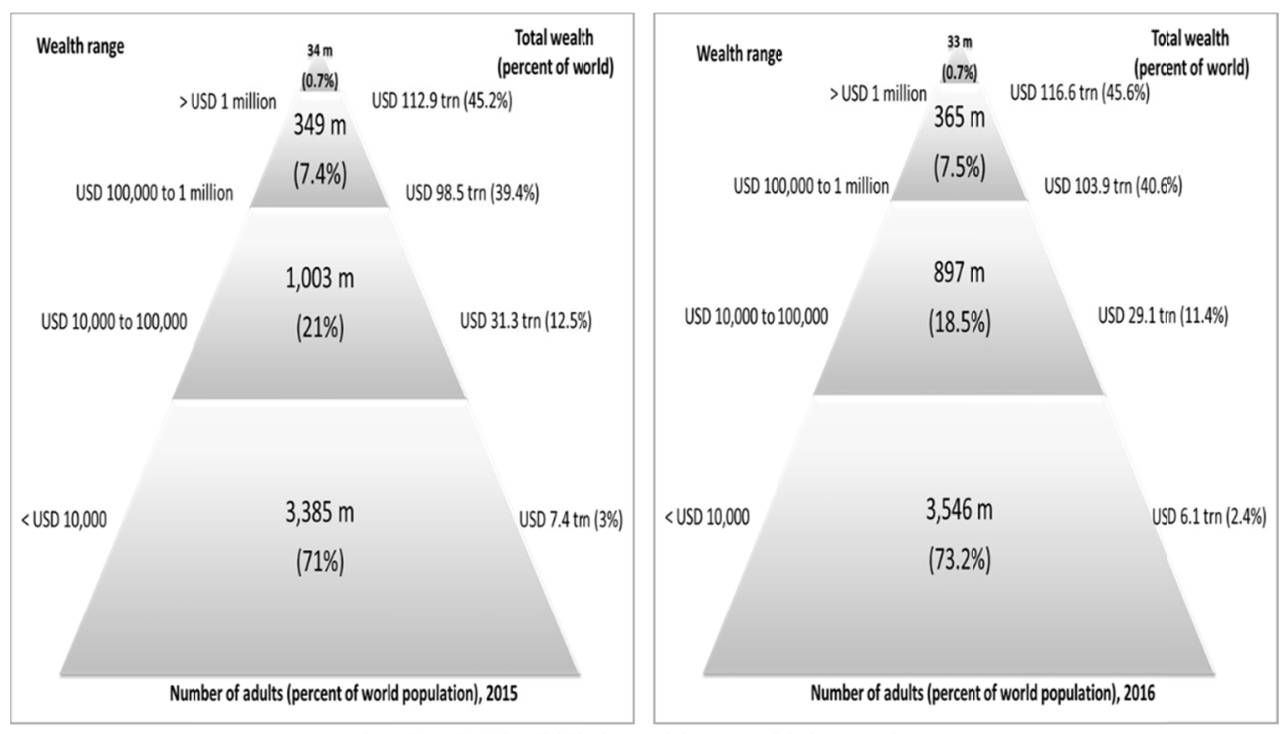

Graph - 1. The Global Wealth Pyramid Comparison

Source: Credit Suisse Research Institute, Global Wealth Report 2015 and 2016

In $2015,71 \%$ of the world's adult population only shared $3 \%$ of the total global wealth, while in 2016 , this base increased to $73.2 \%$ of the adults sharing only $2.4 \%$ of the total wealth. We are talking about 161 million more people sharing $0.6 \%$ less wealth than the previous year.

Conversely, we see how the people in a wealthier income sector (earning between USD 100,000 to one million), comprising only $7.5 \%$ of the world population, increased their amassment of wealth by $1.6 \%$ in only one year. The same condition is seen at the very top of the pyramid, where not even $1 \%$ of the world's adult population ( $0.7 \%)$, accumulated an extra $0.4 \%$ the world's wealth, in spite of there being one million less people in that income range than in 2015.

Even with a difference of only one year, the gap between rich and poor has widened as the world's wealth distribution moves from the bottom to the top of the pyramid. As time passes, there is less wealth distributed among the majority, and more wealth concentrated into a few rich hands.

World economic growth has only benefited the richest people, and the neoliberal model that rules the global system is responsible for it. Due to the co-dependent relationship between core and periphery nations - where multinational corporations rule the global economy, international trade, and world labor markets - this forces the great majority of the world population to accept and survive within that dominated system based on labor exploitation, economic scarcity, and inequality.

As stated by Bourguignon (2016), inequality may have diminished on a global scale. This is mainly due to the empowerment of some emerging economies, such as India and China, and their convergence with the developed world. Being two huge emerging economies, these Asian giants have had a great impact on the global numbers. Nevertheless, within the national scope, these two countries and other similar nations are still suffering tremendous economic disparities among their citizens, proving that inequality within individual nations continues to grow. 


\subsection{Social Deviations as Consequences of Global Inequality}

As the world grows more unequal, social chaos increases as well. There are specific dilemmas directly involved in this cause-effect situation, such as demographic explosion, uncontrolled mass migration, ageing, and scarcity, among others, which are becoming key triggers of the economic system's decline.

The decades to come will represent an enormous challenge for the world order due to the four world population megatrends that the United Nations has forecast for the coming decades:

- The relative demographic bonus of the core countries will diminish around $25 \%$.

- Developed nations' labor force will age and decrease dramatically; thus, economic growth will be limited.

- The majority of the world's population growth will be clustered in the poorest and youngest countries.

- Most of the global world population will already be urbanized, and that population will also be located in the most periphery nations, where access to basic public services is scarce (Goldstone, 2010).

Let us explore the main dilemmas related to these megatrends.

\subsubsection{Demographic Explosion}

Since the first Industrial Revolution (1750 - 1850), when steam engines were invented, labor relations, social life, urbanization, consumerism, and capital acquiring changed dramatically. People living in rural regions massively moved into urban cities to be part of the newly industrialized societies, where they were able to get a wage-paying job in the factories (Inglehart, 2016). Children as young as 5 years old and women were introduced into the labor force, working shifts of 16 hours a day, 6 or even 7 days a week. Though the wages were meager, living standards improved: it was better to get "paid" and be able to consume the new products generated from the industrial revolution than to keep on living in the fields with no income at all.

It was in that era where the concepts of "poverty" and "unemployment" were born, when people began to be sorted into diverse social classes, depending on their consumerism and capital amassing capabilities. Former rural farmers became urban workers subjugated to factory owners' job offers. As Karl Marx (2008) creatively explained, bourgeoisie-proletarian relations became the central asset of the capitalist system.

As both industrial revolutions were evolving, population began increasing at a dramatic rate. All the scientific discoveries, technological readiness, and urban facilities of the time led to increased life expectancy (mostly since the $19^{\text {th }}$ century) and families' growing confidence in having more children (rise in fertility rates), at the same time that child mortality decreased. Thus, a demographic explosion began to take place, mainly in United Kingdom and other progressing countries.

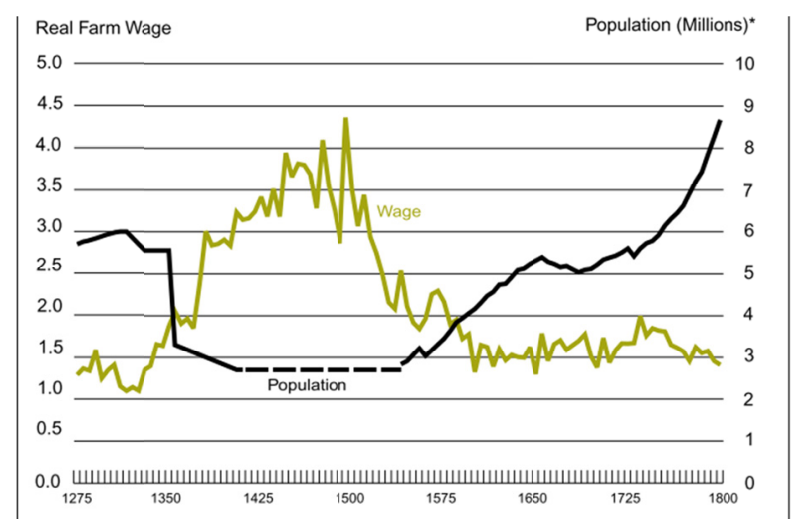

Graph - 2. The English Economy: Population and Real Farm Wage Source: Khan, 2008 based on Hansen and Prescott (2002)

As can be seen in the above chart, population in England experienced a dramatic rise in the late 1700s and the beginning of the $1800 \mathrm{~s}$, precisely when the first industrial revolution was in full swing. Conversely, we see how real farm wages remained low for practically more than two centuries. This phenomenon may have been related to the increase in urban wages, due to the euphoria of the industrial revolution. Real wages in general increased much more after 1800, during the second industrial revolution, when manufacturing sectors had more solid 
diversification of production, thus reinforcing productivity and expanding markets. In England, income per person grew around $0.9 \%$ a year between 1806 and 1906, more than eight times greater than before (Khan, 2008).

Demographic explosion never diminished. On the contrary, it kept and keeps growing so quickly that it has already become a critical condition. After the Second World War, world population increased even faster than in the previous years. The Cold War brought greater opportunities to improve living standards in general due to an increase in technology, products, markets, and consumerism. Since people were more able to get a decent job and wage, this allowed them to grab all the new opportunities the capitalist system offered them. As a result, the new middle class decided to have more children, while child mortality continued shrinking and life expectancy kept growing.

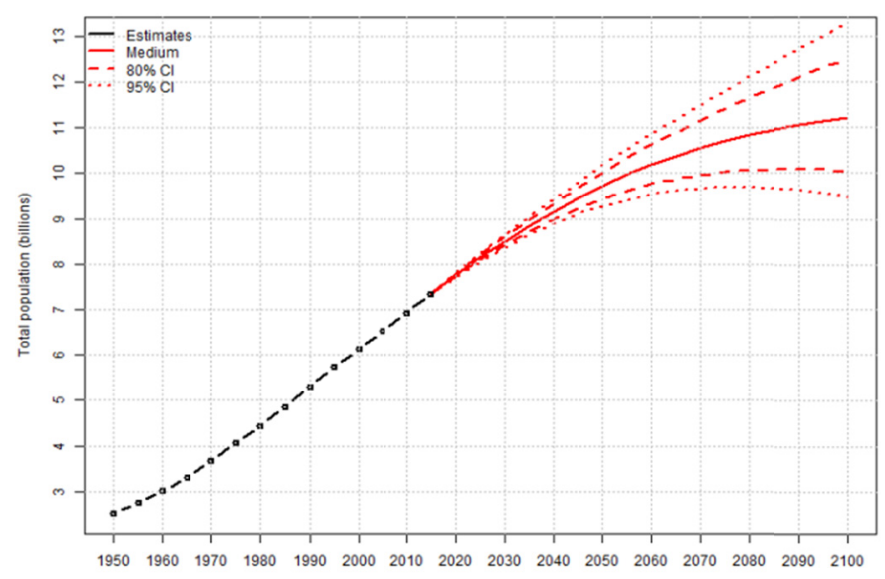

Graph - 3. Population of the world: estimates 1950 - 2015, medium-variant projection and 80 and 95 per cent confidence intervals, 2015-2100.

Source: United Nations, 2015.

As can be seen, we will continue confronting serious problems related to uncontrolled demographic growth throughout the 21st Century. In October 2011, world population reached 7 billion people, and the great majority of them (82.2\%), were clustered in the lowest developed regions (UNFPA, 2011). According to United Nations statistics (2015), we will reach 8.5 billion people by 2030, 9.7 billion in 2050 and 11.2 billion in 2100 .

Periphery nations, mainly in Africa and Asia, are still having as many as 5.8 children per woman. Between 2015 and 2050, Africa will account for more than half the world's population growth, where 28 countries will double their population, and 10 others are projected to increase around fivefold by 2100 (Angola, Burundi, Democratic Republic of Congo, Malawi, Mali, Niger, Somalia, Uganda, United Republic of Tanzania and Zambia) (United Nations, 2015).

As John Wimoth stated:

"The concentration of population growth in the poorest countries presents its own set of challenges, making it more difficult to eradicate poverty and inequality, to combat hunger and malnutrition, and to expand educational enrollment and health systems, all of which are crucial to the success of the new sustainable development agenda." (UNDESA, 2015).

In the near future, there will be millions of poorly educated people from underdeveloped nations looking for jobs and a better life, which their own countries will not be able to offer them. Thus, uncontrolled mass migration to northern countries will become a critical global problem soon.

\subsubsection{Mass Migration}

As previously explained, the industrial revolutions and the post-World War II era clearly accelerated social transformation. Competition for a better job, a better wage, a better car, a better house began dominating the western mentality, due to the fact that industrialized countries (United Kingdom, Germany, France, United States, Japan) were setting market trends that encouraged consumption in their citizens. Mass production in urbanized and industrialized cities led people to look for job opportunities in those places, where they left behind their rural life to become integrated into the manufacturing sector as urbanized paid workers (Fajnzylber, 1983). 
The same reaction occurred with the southern nations' poor, who began migrating to the north in search of better living opportunities. Thus, mass migration started to become a problem.

According to OECD (2017), since the early 1990's, the member countries of the G20 are the ones receiving the majority of the world's immigration, getting an average of 2 million foreigners per year. However, there are great differences across countries. The United States, Germany, and Saudi Arabia are the main destinations, followed by Australia, the United Kingdom and Canada. EU28 hosts 54 million and the United States 47 million immigrants, while China and India, respectively, only get $0.1 \%$ and $0.4 \%$ of the G20's total foreign-born population (OECD, 2017).

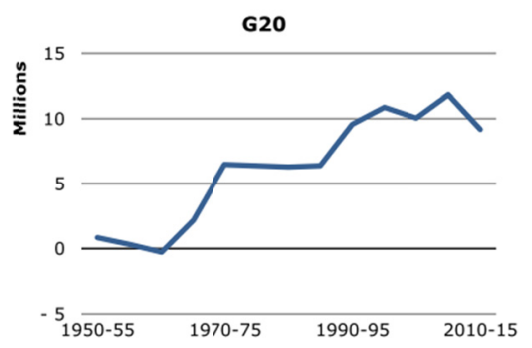

Graph - 4. Net Migration to the G20 1950 - 2015.

Source: OECD, 2017. G20 Global Displacement and Migration Trends Report.

The critical immigration condition that the EU is facing today, due to the Syrian political and security crisis, plus hundreds of north African people trying every day to cross over the European borders, has increased political tension and division among country members to such a degree that the United Kingdom has decided to resign from membership in the EU, mainly due to their refusal to continue accepting foreign immigrants, based on the European bloc's common policies on this matter.

At the same time, the Donald Trump phenomenon includes very powerful, polemic discriminatory propaganda against illegal immigrants, which brings him popularity among his followers. In some ways, both the "Brexit" and Trump phenomena are shocking consequences of mass migration.

Demographic explosion and mass migration combined are leading the global order to an unsustainable condition. This represents a huge challenge, especially for the most developed regions such as Europe, North America, and northeast Asia - where the majority of immigrants will arrive - not only because of the public services they will have to supply in terms of work, housing, health, education, and social integration for foreigners, but also due to the "ageing" problem that most of the industrialized nations are already suffering.

4.2.3 Ageing

Social development brings less fertility and child mortality, and more life expectancy. It results in a process of demographic ageing, characterized by a gradual growth of older adults and a reduction in children's and young people's relative participation. (INEGI, 2013:2).

In most of the world regions, population ageing will occur in the decades to come. The number of older adults (60 years or more) is expected to more than double by 2050 and more than triple by 2100 (United Nations, 2015).

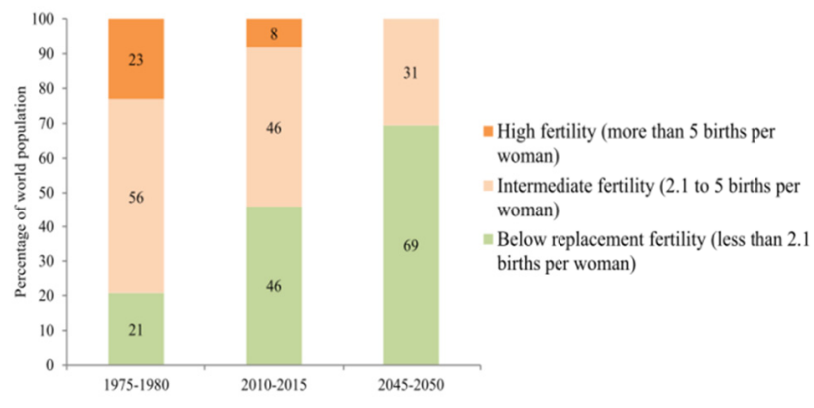

Graph - 5. Distribution of the world's population by level of total fertility, 1975-1980, 2010-2015 and 2045 - 2050. Source: United Nations, 2017. World Population Prospects: The 2017 Revision. New York: Department of Economic and Social Affairs, Population Division. 
Economic prosperity, high quality education, and social planning make northern societies willing to have smaller families in accordance with a long life expectancy. This phenomenon is becoming a big dilemma for the most developed nations due to the fact that mostly of them are already reaching standards of less than 2 children per woman.

According to the World Factbook (CIA, 2017), in Japan the average number of children per woman has decreased to 1.5 , the median age is almost 47 years, and there is a life expectancy of 85 years. Among other issues, this means that a young labor force is not available to maintain the rate of economic growth and productivity. At the same time, Japanese society must support non-productive elderly people for decades. This could cause their economy to collapse.

In the EU and countries such as the United States, South Korea, or Japan, the percentage of people over the age of 60 is between 15 to $30 \%$. By 2050, it is expected to increase to around 30\% (Canada, China and Europe) or 40\% (Japan and South Korea). Just to realize how bad this dilemma really is, Europe expects to lose $24 \%$ of its working-age people in the next 30 years (Goldstone; 2010).

As we can see in the chart above, life expectancy in most of the regions (especially in the most developed areas such as North America and Europe) will continue permanently growing, while Africa will continue lagging far behind in relation to other regions, even though the African continent is projected to have increased its life expectancy by 11 years in 2050. Asia, Europe, Latin America and the Caribbean will gain around $6-7$ years in life expectancy by 2045 - 2050, and Oceania and Northern America will gain 4 -5 more years (United Nations, 2017).

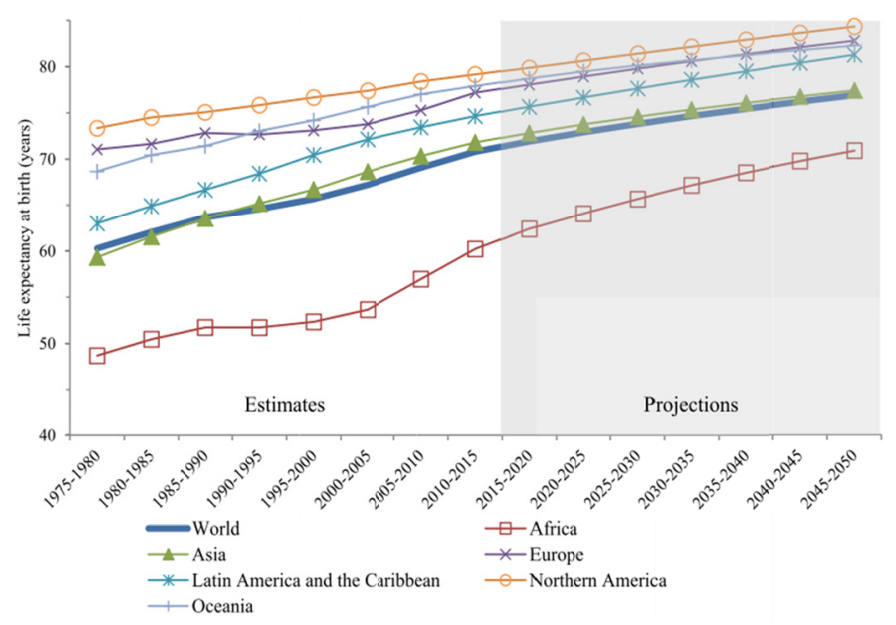

Graph - 6. Life expectancy at birth (years) by region: estimates 1975 - 2015 and projections $2015-2050$.

Source: United Nations, 2017. World Population Prospects: The 2017 Revision. New York: Department of Economic and Social Affairs, Population Division.

Over time, there will be fewer active workers, while the number of retired people will continue growing. This means that core countries will urgently need a labor force while periphery nations will be in need of more jobs for their massive young, unemployed, unqualified population.

\section{Discussion}

The figures and topics described above demonstrate how inequality is not just a big issue in and of itself: it also leads to other correlative social problems that may drive the global system into an irreversible decline. Below we will analyze the main conclusions deriving from this critical reality:

- Reaffirming what Thomas Piketty (2014) wisely stated: economic inequality is an inherent feature of capitalism. It is a system structured and based on dominant-subordinate relationships, where the rich obtain power and control over the worldwide economy and markets, while the poor are relegated to accepting oppression by the rich, for whom they will work in very limited conditions in order to survive. Throughout the entire capitalist era economic inequality has existed; the only difference now is that the situation has become extremely exacerbated. 
- The enormous disparities in income distribution and economic power worldwide have to do with what Buckley and Casson (2010) call competitive individualism versus voluntary association. According to these authors, the western culture is mainly influenced by individualistic competitiveness--a capitalist strength that underdeveloped societies do not share. Competitive individualism allowed the merchant to act freely in order to serve his own economic interests. In this perspective, the interference of other matters with paternalistic purpose is unacceptable (Buckley \& Casson, 2010:81). To the contrary, less developed countries promote voluntary association with each other in order to cooperate, be well-integrated, and improve their living standards by means of reciprocal comradeship. Individualism is not a part of their culture, as neoliberal tendencies have not really reached their social structure. Voluntary association strives for the welfare of the entire community; thus, their co-dependency makes it difficult for them to obtain efficient business results. Therefore, it is easier for developed countries to invade those "rudimentary" societies, getting access and control over those massive markets. This crude discrepancy, which reasserts what the Globalist theory states, causes us to conclude that there are minimum alternatives for southern nations to overcome their underdeveloped status. They will continue being subordinate to the dominant northern world as long as they continue in the mindset of voluntary association.

- Real income in general has stagnated or declined for those who are further down in the productive chain, while large capital gains are made and centered in northern nations and/or in hands of only a few extremely rich. World wealth is rapidly moving from the south to the north, shrinking the share of capital to unsustainable levels. Opportunities for better living standards are aligned with wealth distribution. Those born in prosperous nations will get more access to high quality education, health care, housing, and human development - thus, more access to capital - than those with no access to those assets.

- The excessive neoliberal manifestation into which capitalism has fallen, has triggered not only inequality, but also other social deviations that soon will no longer be manageable. Demographic explosion, mass migration, and ageing are direct consequences of capitalism, and they empower economic inequality. It is a vicious cycle. For instance, demographic explosion is a result of more fertility and less mortality rates. That phenomenon brings more consumption, production, competition, and markets, as more people means more active workers and then, more consumers. However, it conversely also brings uncontrolled mass migration, mainly from people moving from periphery nations to industrialized countries which are supposedly able to cover those basic needs for them. A huge supply of a non-qualified, unemployed labor force must compete with each other for any kind of precarious jobs in order to survive in their countries of origin, forcing them to look for better living opportunities abroad. This is again the co-relationship between domination and subordination, where the most vulnerable people struggle to survive in an economic system controlled by the most powerful.

- $\quad$ Ageing is also a social deviation related to domination and subordination. As the quality of life improves mainly in the developed world, less fertility and more life expectancy is the result. Core countries with high standards of human development have arrived at an extreme manifestation of this: they are now struggling with an increasingly elderly population that is not being replaced with youth. There is no active labor force to support the national economic efficiency standards, so they must resort to immigrant labor. We can foresee how bad this issue can get, when the immigrant population is mainly composed of poorly educated, unskilled workers who are not socially integrated into the receiving societies. What capitalism once reaped as human benefits are now becoming the critical dilemmas that must be solved in order to allow the economic system to survive.

\section{Proposals}

Though economic inequality has been a reprehensible aspect of capitalism from the very beginning, it hasn't been until the last few decades where we have come to a wider awareness of just how critical this problem is.

As we have seen, income distribution inequality, has to do with a rotten capitalist system. There is no other way to make this economic system.to succeed unless we keep the restraining divergent relation on of dominants subordinated. It makes us to agree with Karl Marx, when he stated that as long as capitalism keeps ruling the world, there won't be opportunity to develop any other forms of global governing. Our human nature determines our individualistic manner and permanent competion veness that we stress with each other every single day.

Capitalism shall come into its own colapse, showing us its rudest deviations (greed, power abuse, discrimina on, intolerance), by means of hunger, civil war, scarcity and social chaos. We are not far from that, and it may be the one and only lead for us to make consciousness of the self-destruction we are running to. Even we see how capitalism is declining today, it may be centuries yet to come, with the exacerbation of its deviations. Therefore, as an innovative economic model is not feasible in the short term, we shall apply other partial alternatives that help us to aleviate the chaos. Like Compassionate Capitalism. This concept refers to the possibility of lighten in the exacerbation of capitalism, giving a breath to those in the lowest sectors of the chain. It 
intends to leverage the positive aspects of capitalism, like private property, free markets, liberal economy, but retaking some mercan list assets. Like government economical intervention, internal market consolidation, states' responsibility over social wellbeing, in terms of fair income distribution cannalized to education, labor training, research \& development, technological redness, etc. That would permit the economical success of capitalism, and the equalization of the less developed ones

Income distribution inequality is a basic element of capitalism. There is no other way to make this economic system succeed unless we maintain the repressive, divergent relationship of dominants over the subordinated. This causes us to agree with Karl Marx's vision, when he stated that as long as capitalism continues ruling the world, there will be no opportunity to develop any other forms of global governance. Capitalism allows us to exercise our most individualistic and ambitious human nature, thus we permanently focus on competition with one another. That cannot lead us to a good end.

Capitalism is already showing us its crudest deviations (greed, power abuse, discrimination, unfair trade, over-amassing of capital), resulting in hunger, scarcity, unchecked mass migration, urban overcrowding, precarious jobs and wages. Social discontent is present in the majority of the world population. We are not far from social chaos, though hitting rock bottom might be the one and only way for us to create awareness of the self-destruction we are driving ourselves to.

One of the biggest issues that has made capitalism so powerful is the laissez-faire policy that corporate conglomerates enjoy. They are free to develop their self-interest strategies in order to obtain maximum profits from the system. Since they hold economic and market control, they have a big influence over global governing. They can manipulate laws, market trends, global prices, exchange rates, and obviously income distribution and wealth amassing.

So, how do we expect to create a better economical balance if enterprises and international banking (besides controlling economic and market trends) have the full benefit of laissez-faire?

Even though capitalism is coming into its own decline, it may yet be centuries to come before it arrives at a total collapse. Therefore, because an innovative economic model is not feasible in the short term, we shall apply other partial alternatives that enable us to alleviate the problems of global imbalance. Compassionate Capitalism could be one of them. This concept refers to the possibility of lightening up the exacerbated liberal tendencies of capitalism, giving breathing room to those on the lowest rungs of the economic ladder. This would be done not by avoiding capitalism; rather, we would be making it more flexible. Compassionate capitalism seeks to provide leverage for the positive aspects of the capitalist system, such as private property, free markets, and liberal economy, while the state retakes its ruling role over the economy in order to fairly channel the profits towards improving human welfare.

Economic intervention by the state is the one alternative able to combat capitalist deviations since it offers better control over corporate practices, internal market consolidation, income distribution, and human development improvement. This is done by enforcing education, health, research \& development, job training - an alternative which combines the economic success of capitalism with the compassion of social welfare.

Nowadays we find this intriguing political strategy put in place in some advanced economies, mainly in Europe, which is the least unequal region on earth. The most advanced countries, in terms of human development, are governed by compassionate capitalist tendencies, making access to public services and life opportunities more equal for everybody. They mandate income distribution measures, regulate corporate competition, wage levels, job creation, and access to healthcare and education, effectively channeling all the profits. This kind of governing is called social democracy, also known as the third way, as it combines the greatest advantages of capitalism with those of socialism, combining the best of the two options into one. It advocates a varying synthesis of center-right economics and center-left social policies.

Compassionate capitalism is also directly related to Corporate Social Responsibility. This is a relatively new concept regarding how companies are willing to act, not just for the sake of profits but also for moral and social responsibility in economic, social and environmental contexts (Cuevas \& Rodríguez, 2017). Every day there are more and more corporations integrating socially responsible actions into their internal structure. There is a relatively positive change in the corporate mindset. However, from a general perspective, corporate social responsibility is still subjugated to capital. It means that social responsibility as a corporation mainly lies below its economic interests. As long as it does not interfere with the corporate profit goals, then social responsibility can be manageable. In fact, many corporations make incursions into the realm of social responsibility only because it might give them a better image with their customers. There are no moral objectives, only capital. That is precisely 
why we insist on the imperative necessity for economic intervention from the state: it is the only way to diminish corporate power and cause compassionate capitalism to flourish.

On an international level, there have been some other very interesting proposals regarding compassionate capitalism, which address the issue of how income can be better distributed throughout the world.

Tobin tax may be one of the most practical alternatives that have been proposed for reducing economic disparity. Basically the idea is to establish a minimum tax on worldwide monetary transactions. When US economist James Tobin suggested this tax plan in 1972, it was intended to control exchange rate volatility, stimulate productive investment, and discourage speculation. In fact, nothing was said about income distribution inequality. Even so, in the wake of the 21 st century, Tobin's proposal was again taken up by those against free trade and globalization, referring to it as a feasible alternative for driving development, alleviating economic scarcity and global income distribution disparity.

According to Ramonet (2003), if we would have taxed all financial transactions in the early 2000's with a token rate of $0.1 \%$, there would have been a total annual amount collected of 160 billion dollars, which could be used to amortize southern external debt, alleviate extreme poverty, or improve access to basic universal public services in the most vulnerable countries. Today, the total amount we could collect would be much larger. With a tax rate of only $0.05 \%$ imposed on financial transactions worldwide, the capital collecting potential would be more than 661 billion dollars, which was equivalent to $1.21 \%$ of world GDP in 2011 (CINU, 2011).

Following the economic crisis of 2008, the Tobin tax was endorsed by regional decision makers, governments and international organizations. Such is the case of the European Union (EU), when in 2011 it proposed the Financial Transaction Tax (FTT), seeking to levy all financial asset transactions carried out in the secondary market. Tax rates would be around $0.1 \%$ for all share and bond transactions (Teruel, 2011). At the same time, the Economic Commission for Latin America and the Caribbean (ECLAC) backed the idea of a global financial and/or monetary transaction taxation, which would begin profoundly reforming the international financial system and its institutions, diminishing financial vulnerability and maintaining stability (CINU, 2011). There is no consensus yet among EU members or the global decision-makers to materialize these kind of proposals. There are divergent and ambitious political interests that have blocked negotiations. Nevertheless, the involvement of global analysts and politicians is a good start for the change.

Thomas Piketty's proposal (2014) is also related to taxation. He argues that we are on our way back to patrimonial capitalism, in which a big part of global wealth, which is concentrated in a few hands, is inherited. Therefore, a global framework of patrimony progressive taxation may help to reduce inequality and over-amassing by a very small minority.

Both seem to be great options for transferring a symbolic amount of the world's total wealth from north to south. Nobody could avoid the tax payment, as every single international financial transaction would be charged; thus, the entire global economy would be contributing with the same proportionate amount $(0.1 \%)$, maintaining fair economic competition in general.

Though these are great ideas, it is important to be aware of how difficult it is to bring these proposals to fruition, as the core countries and their giant corporations are the ones in control of the economic system. Being the great capital holders and the rulers of the system, they have the heaviest influence on governmental decision-making and lobbying to serve their own interests. Compassionate capitalism is then in the hands of the citizens. Ordinary citizens, along with the influential intellectuals and international organizations that are already backing these proposals, are the ones with the power to put pressure on national and global governance; among other actions, activism, citizen involvement, and information dissemination are required in order to expand awareness.

The global order is not sustainable in its current unbalanced condition. Political consensus on how to transform the international financial system to make it more equal, stable and fair, is an imperative that the international community cannot just ignore. Worldwide economic disparity may very well bring us to irreversible social chaos, with disastrous consequences. We still have time to reverse it, applying the appropriate corrective measures mentioned above. Thus, it is everybody's responsibility to be informed, to make consciousness, to spread the voice, to put pressure on people, governments and corporations, in order to direct the change.

\section{Acknowledgements}

I would like to thank Ms. Julie Kay Menasco, providing essencial language help and Universidad Anáhuac (Campus Cancun), for all the academic and financial support. 


\section{References}

Bourguignon, F. (January / Febraruy 2016). Inequality and Globalization. How the Rich Get Richer as the Poor Catch Up. Foreign Affairs, 95(1), 11-15.

Buckley, P., \& Casson, M. (2010). The Multinational Enterprise Revisited. Great Britain: Palgrave Macmillan.

Central Intelligence Agency (CIA). (2017). The World Factbook Report. Retrieved from https://www.cia.gov/library/publications/resources/the-world-factbook/geos/ja.html

Centro de Información de las Naciones Unidas (CINU). (2011). Propone CEPAL impuesto global a transacciones financieras [ECLAC proposes a global tax for financial transactions]. Retrieved from http://www.cinu.mx/noticias/la/cepal-pugna-por-impuesto-a-tra/

Ceratti, M. (2014). Cómo reducir la pobreza: ¿nueva lección de Brasil para el mundo? [How to reduce poverty: new lesson from Brazil to the world?]. United States: World Bank, March 22th, 2014. Retrieved from: http://www.bancomundial.org/es/news/feature/2014/03/22/mundo-sin-pobreza-leccion-brasil-mundo-bolsafamilia

Credit Suisse Research Institute. (2015) Global Wealth Report 2015. Retrieved from https://publications.credit-suisse.com/tasks/render/file/?fileID=F2425415-DCA7-80B8-EAD989AF9341D4 $7 \mathrm{E}$

Cuevas, R., \& Rodríguez, R. (January - June 2017). Responsabilidad social y ética profesional en la gestión de la administración pública y empresarial [Social responsibility and profesional ethics in public and corporative management]. Pensamiento y Gestión, 42, 1-25.

Fajnzylber, F. (1983). La Industrialización Trunca de América Latina [Truncated Industrialization of Latin America]. Mexico City, Mexico: Nueva Imagen.

Fekadu, K. (2014). The paradox in environmental determinism and possibilism: A literature review. Journal of Geography and Regional Planning, September 2014, 7(7): 132-139.

Goldstone, J. (January / February 2010). The New Population Bomb. The Four Megatrends that Will Change the World. In Foreign Affairs, 89 (1), 31-43.

Guinote, P. (2013). Um Sistema De Educação-Mundo, De Acordo Com Wallerstein? [A System of Education World, according to Wallerstein?]. Retrieved from https://educar.wordpress.com/2013/08/09/uma-educacao-mundo-de-acordo-com-wallerstein/

Haller, A.-P. (2012). Concepts of Economic Growth and Development. Challenges of Crisis and of Knowledge. Economy Transdisciplinary Cognition, 15(1/2012), 66-71. Romania: Romanian Academy Branch of Iasi.

Inglehart, R. (January / February 2016). Inequality and Modernization. In Foreign Affairs, 95(1), 2-10.

Instituto Nacional de Estadística y Geografía (INEGI). (11 July, 2013). Estadísticas a Proposito del Día Mundial de la Población. [World Population Day Statistics]. Aguas Calientes, Mexico: INEGI. Retrieved from http://www.inegi.org.mx/saladeprensa/aproposito/2011

Kauppi, M. \& Viotti, M. (2012). International Relations Theory. United States: MacMillan.

Khan, A. (2008). The Industrial Revolution and the Demographic Transition. Business Review, Q1, 9-15. United States: Federal Reserve Bank of Philadelphia.

Marx, K. (2008). El Capital. Mexico: Castellano.

Organization for Economic Cooperation and Development (OECD). (2017). G20 Global Displacement and Migration Trends Report. Paris, France: OECD. Retrieved from https://www.oecd.org/g20/topics/employment-and-social-policy/G20-OECD-migration.pdf

OXFAM International. (January 2017). Una economía para el 99\%. [An economy for the 99\%]. Informe OXFAM, Oxford, United Kingdom: OXFAM International. Retrieved from http://www.pensamientocritico.org/oxfami0217.pdf

Piketty, T. (2014). Capital in the Twenty-First Century. London, England: The Belknap Press of Harvard University Press.

Tepperman, J. (January/February 2016). Brazil's Antipoverty Breakthrough. In Foreign Affairs. Retrieved from https://www.foreignaffairs.com/articles/brazil/2015-12-14/brazils-antipoverty-breakthrough 
Teurel, A. (2011). Merkel y Sarkozy lanzan un Gobierno económico para salvar el euro [Merken and Sarkozy launch an economic government to save the euro]. In El Pais, 16.08.2011. Retrieved from https://elpais.com/economia/2011/08/16/actualidad/1313479973_850215.html

United Nations Department of Economic and Social Affairs (UNDESA) (29 July, 2015). World population projected to reach 9.7 billion by 2050. New York: United Nations. Retrieved from http://www.un.org/en/development/desa/news/population/2015-report.html

United Nations Development Program (UNDP). (2010). Human Development Report 2010. The Real Wealth of Nations. United States: Palgrave Macmillan.

United Nations Development Program (UNDP). (2016). Human Development Report 2016. Human Development for Everyone. United States: Lowe-Martin Group.

United Nations Population Fund (UNFPA). (2011). The State of World Population 2011. May, 2013. New York: United Nations. Retrieved from http://foweb.unfpa.org/SWP2011/reports/SP-SWOP2011_Final.pdf

United Nations. (2015). World Population Prospects: The 2015 Revision. New York: Department of Economic and Social Affairs, Population Division.

United Nations. (2017). World Population Prospects: The 2017 Revision. New York: Department of Economic and Social Affairs, Population Division.

Wallerstein, I. (2004). World-Systems Analysis: An Introduction. Durham, NC: Duke University Press.

\section{Copyrights}

Copyright for this article is retained by the author(s), with first publication rights granted to the journal.

This is an open-access article distributed under the terms and conditions of the Creative Commons Attribution license (http://creativecommons.org/licenses/by/4.0/). 